\title{
Perspectives of febrile convulsions among parents: a local cross-sectional study
}

\author{
Latifah Abdulrahim Alhashim', Ossama Mohammed Zakaria2*, Muneera Adel Alrubayii ${ }^{1}$, \\ Asma Salah Alkhofi', Sarah Khalid Alateeq ${ }^{1}$, Maitha Khalid Almaghlouth', Reema Mohammed Almulla', \\ Ahmed Abdulrahman Al Abdulqader ${ }^{3}$, Latifah Abdullah Almulhium ${ }^{4}$ and Abdulrahman Ahmad Alnaim ${ }^{1}$
}

\begin{abstract}
Background: Globally, febrile convulsions $(F C)$ constitute a respected prevalence scale among pediatric population. This usually induces a high parental anxiety.

Aim: To investigate the local community diversity of perception as regards FC.

Method: A cross-sectional anonymous Arabic questionnaire-based study took place targeting the Saudi community. The study included parents with at least a child who underwent FC. Excluded, were those who have children with convulsions due to other causes rather than FC.

Results: Eight hundred participants have fulfilled the study inclusion criteria. Majority of them (84\%) were mothers. While 10.9\% had only one child diagnosed with FC. Participants believed that FC may induce brain damage (41.4\%). Others expressed FC attacks to be life-threatening events (52.9\%). They were convinced that FC is not related to epilepsy (40.2\%). However, a respected percentage of participants denoted the importance of using oral protective devices during the attacks (41.4\%). Overall, most study population (84\%) had poor perception of the different aspects of FC.

Conclusion: Social perception of FC problems may be significantly related to the educational level and profession of the parents. The majority of the study subjects have poor perception as regards FC. Therefore, holistic socially oriented educational programs are needed to orient the population about the problem. They may be implemented via various approaches.
\end{abstract}

Keywords: Febrile convulsions, Epilepsy, Infantile seizure

\section{Background}

Febrile convulsions (FC) are among the commonly encountered benign clinical conditions within the pediatric population. They usually present among infants and children up to the age of 5 years [1].

FC are defined by The International League Against Epilepsy (ILAE) as seizures that occur in children since

\footnotetext{
*Correspondence: ossamaz2004@gmail.com

${ }^{2}$ Division of Surgical Pediatric, Department of Surgery, College

of Medicine, King Faisal University, Hofuf, Saudi Arabia
}

Full list of author information is available at the end of the article their early infantile age because of fever and not related to the central nervous system (CNS) causes [2].

They occur when the temperature reached more than $38^{\circ} \mathrm{C}[1,3]$. FC are not related to previous neonatal and/ or unprovoked seizures. Moreover, they do not simulate other acute symptomatic seizures $[2,3]$.

Although the prevalence of FC have been discussed and highlighted in the literature [4-8], little were published as regards Saudi populations [3]. None the less, there is no international agreement concerning FC prevalence. It was reported that the peaked FC is around 2-3 years of life with an average rate $6.92 \%$ [5]. 
FC have an unclear etiology, yet, they proofed to have a familial tendency [1]. They may present as simple or complex seizures. Simple seizures account for $80-85 \%$ of FC [7]. However, those children with complex FC usually suffer of prolonged drowsiness that follows the increased temperature $[7,9]$.

Most parents, especially those who had an FC child for the first time, may be terrified as they consider it a lethal condition [10-12].

Most of them are intimidated by the notion that FC may lead to epilepsy, brain damage, as well as long-life physical disabilities $[1,13]$.

Hence, most parents do not properly respond to FC management $[7,14]$.

It is of paramount importance that knowledge about FC should be available to all society members.

The current study aimed to gauge the nation-wide parental perception of FC problem. Obtained results would be assets to create a realistic and holistic socially oriented educational program related to FC.

\section{Method}

The current study took place on a national level. It recruits the whole parental population. The questionnaire was designed and validated based on initial pilot study. Validation was done with applying the Cronbach alpha equation aiming to measure the internal consistency and validity of the questions within the questionnaire.

The questionnaire constituted three sections: the first was the participants' demographical data such as age, sex, professions, and education.

The second section was concerned with the children's data such as gender, age, presence of FC, etc.

The third section included questions related to the parents' knowledge, concern, attitude, and practice towards FC.

The study initially involved 1000 participants. Yet, 800 were indulged as they met the inclusion criteria.

The excluded two hundred responders were those who have no children or did not fully respond to the questionnaire. Also, children with previous afebrile seizures, neurological disorders, CNS infections, and seizures with drug withdrawal were excluded.

Re-validation of the questionnaire as well as statistical analysis of the obtained data were done using Statistical Package for the Social Sciences (SPSS) version 22. Data were analyzed using two-tailed tests. A $p$ value less than 0.05 was considered statistically significant.

\section{Results}

Eight hundred participants responded to the questionnaire. Out of them, 674 (84\%) were mothers. Their ages ranged from 18 to 60 years with a mean of $43.6 \pm 12.4$ years. Six hundred and twenty-nine $(78.6 \%)$ were university graduates. Sixteen $(2.0 \%)$ had not completed secondary school education. Parents' professions and parity levels are shown in Table 1.

Information of families who have children with $\mathrm{FC}$ is illustrated in Tables 2 and 3.

Tables 4 thoroughly express the result for the rest of the questions.

Table 5 highlights the relationship between knowledge in relation to education and the profession of the parents. The parents' perception about their future progeny is shown in Fig. 1.

A Low percentage of perceptions is considered when below 60 .

\section{Discussion}

Febrile seizures are commonly presented as benign convulsions among the pediatric population. The condition is highly intimidating to the children's family [1]. The current qualitative study took place to investigate this notion.

Eighty-seven (10.9\%) of the study population showed only one FC child. Prevalence of the initial attack

Table 1 Personal data of respondent parents in Eastern region, Saudi Arabia

\begin{tabular}{|c|c|c|}
\hline Parents personal data & No & $\%$ \\
\hline \multicolumn{3}{|l|}{ Respondent } \\
\hline Father & 128 & $16.0 \%$ \\
\hline Mother & 672 & $84.0 \%$ \\
\hline \multicolumn{3}{|l|}{ Age in years } \\
\hline $18-30$ & 198 & $24.8 \%$ \\
\hline $31-40$ & 225 & $28.1 \%$ \\
\hline $41-50$ & 244 & $30.5 \%$ \\
\hline $51-60$ & 133 & $16.6 \%$ \\
\hline \multicolumn{3}{|l|}{ Educational level } \\
\hline Below secondary & 16 & $2.0 \%$ \\
\hline Secondary & 155 & $19.4 \%$ \\
\hline University/above & 629 & $78.6 \%$ \\
\hline \multicolumn{3}{|l|}{ Mother job } \\
\hline Housewife & 330 & $41.3 \%$ \\
\hline Student & 61 & $7.6 \%$ \\
\hline Health care worker & 34 & $4.3 \%$ \\
\hline Non-health care worker & 375 & $46.9 \%$ \\
\hline \multicolumn{3}{|l|}{ Father job } \\
\hline Notworking & 78 & $9.8 \%$ \\
\hline Health care worker & 60 & $7.5 \%$ \\
\hline Non-health care worker & 662 & $82.8 \%$ \\
\hline \multicolumn{3}{|l|}{ Children } \\
\hline One child & 127 & $15.9 \%$ \\
\hline$>1$ child & 673 & $84.1 \%$ \\
\hline
\end{tabular}


Table 2 Febrile convulsions related data with family concern and practice, Eastern region, Saudi Arabia

\begin{tabular}{|c|c|c|}
\hline FC related data & No & $\%$ \\
\hline \multicolumn{3}{|l|}{ Had child with FC } \\
\hline No & 713 & $89.1 \%$ \\
\hline Yes & 87 & $10.9 \%$ \\
\hline \multicolumn{3}{|l|}{ Age of first FC attack $(n=87)$} \\
\hline $6-12 \mathrm{~ms}$ & 35 & $40.2 \%$ \\
\hline $1-2$ years & 18 & $20.7 \%$ \\
\hline $2-3$ years & 24 & $27.6 \%$ \\
\hline $3-5$ years & 10 & $11.5 \%$ \\
\hline \multicolumn{3}{|l|}{ Child gender $(n=87)$} \\
\hline Male & 35 & $40.2 \%$ \\
\hline Female & 52 & $59.8 \%$ \\
\hline \multicolumn{3}{|l|}{ FC was repeated $(n=87)$} \\
\hline Yes & 32 & $36.8 \%$ \\
\hline No & 55 & $63.2 \%$ \\
\hline \multicolumn{3}{|l|}{ What made you worry after having child with FC $(n=87)$} \\
\hline Nothing made me afraid & 4 & $4.6 \%$ \\
\hline Fear of being fevered again & 35 & $40.2 \%$ \\
\hline $\begin{array}{l}\text { Fear of potential brain damage that affect the child's } \\
\text { development }\end{array}$ & 36 & $41.4 \%$ \\
\hline Fear of risk of subsequent epilepsy & 25 & $28.7 \%$ \\
\hline Fear of that siblings will have FC too & 13 & $14.9 \%$ \\
\hline Fear that the child will die & 35 & $40.2 \%$ \\
\hline \multicolumn{3}{|l|}{ First behavior during FC attack $(n=87)$} \\
\hline Try to lower the child's body temperature & 22 & $25.3 \%$ \\
\hline Place the child on his/her side & 8 & $9.2 \%$ \\
\hline Rush the child to a doctor & 44 & $50.6 \%$ \\
\hline Suck discharge from the child's nose and mouth & 6 & $6.9 \%$ \\
\hline Shake and rouse the convulsing child & 4 & $4.6 \%$ \\
\hline Protect the child on a soft and safe surface & 1 & $1.1 \%$ \\
\hline Attempt mouth-to-mouth resuscitation & 2 & $2.3 \%$ \\
\hline \multicolumn{3}{|l|}{ What directed you to do such behavior during FC $(n=87)$} \\
\hline I acted unconsciously & 50 & $57.5 \%$ \\
\hline Physician & 15 & $17.2 \%$ \\
\hline Social media & 4 & $4.6 \%$ \\
\hline Books & 4 & $4.6 \%$ \\
\hline Previous experience with family member & 5 & $5.7 \%$ \\
\hline Others & 9 & $10.3 \%$ \\
\hline
\end{tabular}

among their children was (29.9\%). In a similar study, the FC prevalence was reported as $37 \%$ in the same pediatric age group [12].

On the other hand, a report from a different geographical area stated a higher percentage $(50 \%)$ of toddlers with FC [15].

In the current study, 52 (59.8\%) of children were girls. Among them, about $37 \%$ have repeated FC attacks. This data contradicts other literature that express a higher
Table 3 Distribution of family attitude towards febrile convulsions according to having child with FC

\begin{tabular}{|c|c|c|c|c|c|}
\hline \multicolumn{6}{|c|}{ Had child with FC } \\
\hline \multirow[t]{2}{*}{ Attitude items } & \multicolumn{2}{|l|}{ No } & \multicolumn{2}{|c|}{ Yes } & \multirow[t]{2}{*}{$P$ value } \\
\hline & No & $\%$ & No & $\%$ & \\
\hline \multicolumn{6}{|c|}{ FC is due to possession by spirits } \\
\hline Disagree & 443 & $62.1 \%$ & 70 & $80.5 \%$ & \\
\hline Neutral & 234 & $32.8 \%$ & 14 & $16.1 \%$ & $.003^{*}$ \\
\hline Agree & 36 & $5.0 \%$ & 3 & $3.4 \%$ & \\
\hline \multicolumn{6}{|c|}{ FC attack is a life-threatening event } \\
\hline Disagree & 118 & $16.5 \%$ & 24 & $27.6 \%$ & \\
\hline Neutral & 245 & $34.4 \%$ & 17 & $19.5 \%$ & $.005^{*}$ \\
\hline Agree & 350 & $49.1 \%$ & 46 & $52.9 \%$ & \\
\hline
\end{tabular}

FC can cause brain damage which affects the child's mental and intellectual development in the future

$\begin{array}{lccccc}\text { Disagree } & 82 & 11.5 \% & 16 & 18.4 \% & .043^{*} \\ \text { Neutral } & 254 & 35.6 \% & 21 & 24.1 \% & \\ \text { Agree } & 377 & 52.9 \% & 50 & 57.5 \% & \\ \text { Herbal remedies can } & \text { help to manage FC } & & & \\ \text { Disagree } & 414 & 58.1 \% & 67 & 77.0 \% & .003^{*} \\ \text { Neutral } & 258 & 36.2 \% & 18 & 20.7 \% & \\ \text { Agree } & 41 & 5.8 \% & 2 & 2.3 \% & \end{array}$

More attention and care are needed for a child with FC

\begin{tabular}{llllll} 
Disagree & 21 & $2.9 \%$ & 5 & $5.7 \%$ & .284 \\
Neutral & 81 & $11.4 \%$ & 12 & $13.8 \%$ & \\
Agree & 611 & $85.7 \%$ & 70 & $80.5 \%$ & \\
tt is shameful to have a child with FC & & & \\
Disagree & 625 & $87.7 \%$ & 82 & $94.3 \%$ & \\
Neutral & 67 & $9.4 \%$ & 5 & $5.7 \%$ & .129 \\
Agree & 21 & $2.9 \%$ & 0 & $0.0 \%$ & \\
\hline
\end{tabular}

P Pearson $x 2$ test

${ }^{*} P<0.05$ (significant)

incidence of FC among boys compared to girls [1, 12, 15-17].

Parents' ages at our study ranged from 18 to 60 years. Majority of them were university graduates. This partially coincides with a similar publication that showed an age range from 15 to 50 years, yet, more than $50 \%$ of the participants attained primary education [15]. In contrast, others reported $100 \%$ of mothers have no formal education [14].

It was reported that variations in educational level are the main pivot for the different parental FC perception $[12,17,18]$. In contrast, most of our study population was university graduates; yet, they showed limited knowledge and information about the FC problem.

Parents were highly concerned about FC complications. A quite respected percentage (41.4\%) of them had the concept that FC may lead to irreversible brain 
Table 4 Distribution of family knowledge regarding febrile convulsions according to having child with FC

\begin{tabular}{|c|c|c|c|c|c|}
\hline \multicolumn{6}{|l|}{ Had child with FC } \\
\hline \multirow[t]{2}{*}{ Knowledge items } & \multicolumn{2}{|l|}{ No } & \multicolumn{2}{|l|}{ Yes } & \multirow[t]{2}{*}{$P$ value } \\
\hline & No & $\%$ & No & $\%$ & \\
\hline \multicolumn{6}{|c|}{ FC is a type of epilepsy } \\
\hline Correct & 253 & $35.5 \%$ & 13 & $14.9 \%$ & \multirow[t]{3}{*}{$.001^{*}$} \\
\hline Incorrect & 109 & $15.3 \%$ & 35 & $40.2 \%$ & \\
\hline Do not know & 351 & $49.2 \%$ & 39 & $44.8 \%$ & \\
\hline \multicolumn{6}{|c|}{ Anticonvulsant drugs are required for every child with FC } \\
\hline Correct & 128 & $18.0 \%$ & 6 & $6.9 \%$ & \multirow[t]{3}{*}{$.001^{*}$} \\
\hline Incorrect & 162 & $22.7 \%$ & 34 & $39.1 \%$ & \\
\hline Do not know & 423 & $59.3 \%$ & 47 & $54.0 \%$ & \\
\hline \multicolumn{6}{|c|}{ FC is rare after 5 years } \\
\hline Correct & 117 & $16.4 \%$ & 52 & $59.8 \%$ & \multirow{3}{*}{$.001^{*}$} \\
\hline Incorrect & 104 & $14.6 \%$ & 4 & $4.6 \%$ & \\
\hline Do not know & 492 & $69.0 \%$ & 31 & $35.6 \%$ & \\
\hline \multicolumn{6}{|c|}{ It is necessary to restrain the child during convulsion } \\
\hline Correct & 187 & $26.2 \%$ & 20 & $23.0 \%$ & \multirow[t]{3}{*}{$.040^{*}$} \\
\hline Incorrect & 145 & $20.3 \%$ & 28 & $32.2 \%$ & \\
\hline Do not know & 381 & $53.4 \%$ & 39 & $44.8 \%$ & \\
\hline \multicolumn{6}{|c|}{$\begin{array}{l}\text { It is necessary to put a protective device into the mouth to prevent } \\
\text { tongue injury during convulsion }\end{array}$} \\
\hline Correct & 422 & $59.2 \%$ & 36 & $41.4 \%$ & \multirow[t]{3}{*}{$.001^{*}$} \\
\hline Incorrect & 60 & $8.4 \%$ & 16 & $18.4 \%$ & \\
\hline Don't know & 231 & $32.4 \%$ & 35 & $40.2 \%$ & \\
\hline \multicolumn{6}{|c|}{ EEG or CT is necessary for every with FC } \\
\hline Correct & 432 & $60.6 \%$ & 33 & $37.9 \%$ & \multirow[t]{3}{*}{$.001^{*}$} \\
\hline Incorrect & 26 & $3.6 \%$ & 16 & $18.4 \%$ & \\
\hline Do not know & 255 & $35.8 \%$ & 38 & $43.7 \%$ & \\
\hline \multicolumn{6}{|c|}{ Overall knowledge level } \\
\hline Poor & 680 & $95.4 \%$ & 73 & $84 \%$ & \multirow[t]{2}{*}{$.001^{*}$} \\
\hline Good & 33 & $4.6 \%$ & 14 & $16.1 \%$ & \\
\hline
\end{tabular}

P Pearson $\times 2$ test

${ }^{*} P<0.05$ (significant)

damage and developmental retardation. Others (40.2\%) had the notion that continuous fever, epilepsy, and death may be the result of FC. These data are relatively comparable to previous similarly published literature $[1,15,19]$. The different concepts might be explained by the differences in educational and social background.

Many reported a high FC recurrence rate among children who had their initial seizures below the age of 15 months $[7,9,19]$. Children with precures suffering of epilepsy have a higher susceptibility rate to have the complex type of FC-related seizures $[7,20]$.

Such complex FC are also highly presented among children with neurodevelopmental growth retardation [7, 18]. Overall, FC are generally considered a
Table 5 Distribution of family knowledge regarding febrile convulsions according to respondent's personal data and attitude

\begin{tabular}{|c|c|c|c|c|c|}
\hline \multicolumn{6}{|l|}{ Knowledge level } \\
\hline \multirow[t]{2}{*}{ Factors } & \multicolumn{2}{|c|}{ Poor } & \multicolumn{2}{|c|}{ Good } & \multirow[t]{2}{*}{$P$ value } \\
\hline & No & $\%$ & No & $\%$ & \\
\hline \multicolumn{6}{|l|}{ Respondent } \\
\hline Father & 123 & $96.1 \%$ & 5 & $3.9 \%$ & \multirow[t]{2}{*}{.301} \\
\hline Mother & 630 & $93.8 \%$ & 42 & $6.3 \%$ & \\
\hline \multicolumn{6}{|l|}{ Age in years } \\
\hline $18-30$ & 191 & $96.5 \%$ & 7 & $3.5 \%$ & \multirow{4}{*}{.193} \\
\hline $31-40$ & 210 & $93.3 \%$ & 15 & $6.7 \%$ & \\
\hline $41-50$ & 231 & $94.7 \%$ & 13 & $5.3 \%$ & \\
\hline $51-60$ & 121 & $91.0 \%$ & 12 & $9.0 \%$ & \\
\hline \multicolumn{6}{|l|}{ Educational level } \\
\hline Below secondary & 16 & $100.0 \%$ & 0 & $0.0 \%$ & \multirow[t]{3}{*}{$.049^{*}$} \\
\hline Secondary & 151 & $97.4 \%$ & 4 & $2.6 \%$ & \\
\hline University/above & 586 & $93.2 \%$ & 43 & $6.8 \%$ & \\
\hline \multicolumn{6}{|l|}{ Mother job } \\
\hline Housewife & 317 & $96.1 \%$ & 13 & $3.9 \%$ & \multirow{4}{*}{$.010^{*}$} \\
\hline Student & 58 & $95.1 \%$ & 3 & $4.9 \%$ & \\
\hline Health care worker & 28 & $82.4 \%$ & 6 & $17.6 \%$ & \\
\hline Non-health care worker & 350 & $93.3 \%$ & 25 & $6.7 \%$ & \\
\hline \multicolumn{6}{|l|}{ Father job } \\
\hline Notworking & 74 & $94.9 \%$ & 4 & $5.1 \%$ & \multirow[t]{3}{*}{.685} \\
\hline Health care worker & 55 & $91.7 \%$ & 5 & $8.3 \%$ & \\
\hline Non-health care worker & 624 & $94.3 \%$ & 38 & $5.7 \%$ & \\
\hline \multicolumn{6}{|l|}{ Children } \\
\hline One child & 121 & $95.3 \%$ & 6 & $4.7 \%$ & \multirow[t]{2}{*}{.548} \\
\hline$>1$ child & 632 & $93.9 \%$ & 41 & $6.1 \%$ & \\
\hline
\end{tabular}

P Exact probability test

${ }^{*} P<0.05$ (significant)

self-limited pathology with a good prognosis among the pediatric population. The recurrence rate is about (4\%) [7].

We reported $52.9 \%$ of participants believing that $\mathrm{FC}$ is a life-threatening condition. They also thought that it may cause brain damage with a strong affection of their future mental and intellectual development. These conceptual ideas are supported by previously published reports $[7,9$, 12, 18]. This may be attributed to parental fear and anxiety during the attack $[1,12,14]$.

Contradicting other studies, $77 \%$ of our participants did not believe in herbal medicine as a treatment tool for FC $[15,17,19,21]$. Interestingly, the majority of our subjects (94.3\%) did not consider FC as a shameful condition, compared to others who reported more than $50 \%$ of participants believing FC is a stigmatic event [22].

A considerable percentage (40.2\%) of the study population were convinced that FC are not a type of epilepsy 


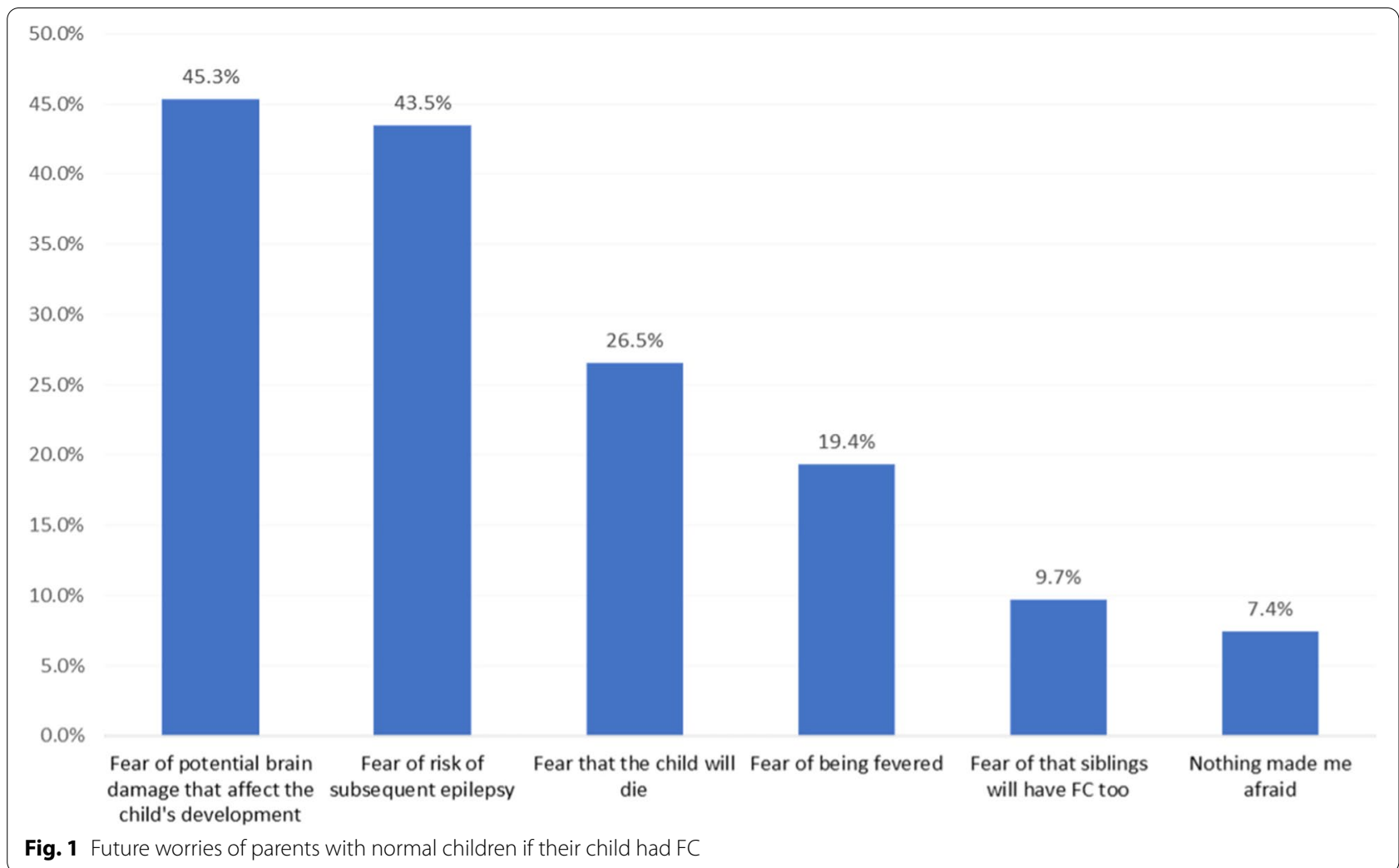

and needs not any antiepileptic therapy. Others denoted $73 \%$ of the population considering FC as an epilepsy that requires pharmacological therapy [15]. The reason is related to the disparity of educational level that may have influenced their overall perception about the problem $[12,13,15,17,21]$.

\section{Conclusion}

It may be concluded that FC social perception is highly related to parents' educational level. The current study subjects showed a limited perception of FC and its allied diseases. Therefore, it is recommended to design and implement special social oriented educational programs to holistically transfer the FC-related information to the community. Audiovisual tools, internet, and newspapers as well as other media tools may be helpful in fulfilling this task. Also, social workers and physicians should play an important role in the matter.

\section{Acknowledgments}

We would like to thank Dr.Gihan Yousef Ali, assistant professor of pediatric from the King Faisal University and Dr.Shehata Ferag Shehata, Assistant professor of community medicine majority biostatistics from King Khalid University for their help in carrying out this study.

\section{Authors' contributions}

L.A. designed the study; M.A and S.K. collected and analyzed data; O.Z, L.A, and A.S. wrote the manuscript, M.K, R.M, A.A, LA, AA revised the manuscript. All authors read and approved the final manuscript.

\section{Funding}

No funding is required.

Availability of data and materials

All data are available on request.

\section{Declarations}

\section{Ethics approval and consent to participate}

The patients' confidentiality and the privacy of their data are the priority. Nothing leads to any ethical issue will be used, such as the names of participants. The ethical clearance given by the ethical committee of college of medicine, King Faisal University.

Reference number: 2020-10-71.

\section{Consent for publication}

Not applicable.

\section{Competing interests}

The authors declare that there are no conflict of interests.

\section{Author details}

${ }^{1}$ Department of Pediatrics, College of Medicine, King Faisal University, Hofuf, Saudi Arabia. ${ }^{2}$ Division of Surgical Pediatric, Department of Surgery, College of Medicine, King Faisal University, Hofuf, Saudi Arabia. ${ }^{3}$ Department of Surgery, College of Medicine, King Faisal University, Hofuf, Saudi Arabia. ${ }^{4}$ Department of Surgery, College of Medicine, Imam Abdul Rahman University, Dammam, Saudi Arabia.

Received: 23 September 2021 Accepted: 25 January 2022 Published online: 01 March 2022 


\section{References}

1. Srinivasa S, Syeda KA, Patel S, Harish S, Bhavya G (2018) Parental knowledge, attitude, and practices regarding febrile convulsion. Int J Contemp Pediatr 5(2):515-519

2. Commission on Epidemiology and Prognosis, \& International League Against Epilepsy (1993) Guidelines for epidemiologic studies on epilepsy. Epilepsia 34(4):592-596

3. Al Rajeh S, Awada A, Bademosi O, Ogunniyi A (2001) The prevalence of epilepsy and other seizure disorders in an Arab population: a community-based study. Seizure 10(6):410-414

4. Delpisheh A, Veisani Y, Sayehmiri K, Fayyazi A (2014) Febrile seizures: etiology, prevalence, and geographical variation. Iranian J Child Neurol 8(3):30

5. Byeon JH, Kim GH, Eun BL (2018) Prevalence, incidence, and recurrence of febrile seizures in Korean children based on national registry data. J Clin Neurol 14(1):43-47

6. Nishiyama M, Yamaguchi $H$, Ishida $Y$, Tomioka $K$, Takeda H, Nishimura N, Nagase H (2020) Seizure prevalence in children aged up to 3 years: a longitudinal population-based cohort study in Japan. BMJ Open 10(9):e035977

7. Leung AKC, Hon KL, Leung TNH (2018) Febrile seizures: an overview. Drugs in Context 7:212536. https://doi.org/10.7573/dic.212536

8. Alruwaili RMR, Almusawi M, Ahmed AJA, ALenezi AT, Alanazi AMS, Alenezi SGE et al (2018) Convulsions in Children, Arar, Northern Saudi Arabia. Egyptian J Hospital Med 71(3):2738-2741

9. Jones T, Jacobsen SJ (2007) Childhood febrile seizures: overview and implications. Int J Med Sci 4(2):110

10. Zeglam AM, Alhmadi S, Beshish A (2010) Auditing the attitude and knowledge of parents of children with febrile seizures. Afr J Neurol Sci 29(1):3-8

11. Kolahi AA, Tahmooreszadeh S (2009) First febrile convulsions: inquiry about the knowledge, attitudes and concerns of the patients' mothers. Eur J Pediatr 168(2):167-171

12. Shibeeb NF, Altufaily YAS (2019) Parental knowledge and practice regarding febrile seizure in their children. Med J Babylon 16(1):58

13. Sajadi M, Khosravi S (2017) Mothers' experiences about febrile convulsions in their children: a qualitative study. Int J Commun Based Nurs Midwifery 5(3):284

14. Oche OM, Onankpa OB (2013) Using women advocacy groups to enhance knowledge and home management of febrile convulsion amongst mothers in a rural community of Sokoto State, Nigeria. Pan Afr Med J 14:49. https://doi.org/10.11604/pamj.2013.14.49.1703

15. Kayserili E, Ünalp A, Apa H, Asilsoy S, Hizarcioğlu M, Gülez P, Agin H (2008) Parental knowledge and practices regarding febrile convulsions in Turkish children. Turkish J Med Sci 38(4):343-350

16. Nahar N, Ahsan CDMA, TajuddinBhuiyan AKM, Tayab MA, Islam A (2019) Clinical aspects of febrile seizures, knowledge, attitude, practice and impactin admitted children and Socio-demographic characteristics of the parents: a study in DhakaShishu (Children) Hospital, Dhaka, Bangladesh. IOSR J Dental Med Sci (IOSR-JDMS) 18(5):17-28

17. Abdulla MM, Abdulhadi FS (2015) Knowledge, attitudes, and practices (KAP) regarding Febrile Convulsions among Iraqi under 5 children's mothers attending pediatric department in a teaching hospital in Baghdad. Int J 3(6):973-983

18. Deng CT, Zulkifli HI, Azizi BH (1996) Parental reactions to febrile seizures in Malaysian children. Med J Malaysia 51(4):462-468

19. Parmar RC, Sahu DR, Bavdekar SB (2001) Knowledge, attitude and practices of parents of children with febrile convulsion. J Postgrad Med 47(1):19

20. Waruiru C, Appleton R (2004) Febrile seizures: an update. Arch Dis Child 89(8):751-756

21. Steering Committee on Quality Improvement and Management, Subcommittee on Febrile Seizures (2008) Febrile seizures: clinical practice guideline for the long-term management of the child with simple febrile seizures. Pediatrics 121(6):1281-1286

22. Sriyani KA, Abesekara MSSK, Wijesena BVTN, Perera RACN, Kuruppu NR (2018) Mothers, knowledge, believes and practices regarding febrile convulsions and home management

\section{Publisher's Note}

Springer Nature remains neutral with regard to jurisdictional claims in published maps and institutional affiliations.

\section{Submit your manuscript to a SpringerOpen ${ }^{\circ}$ journal and benefit from:}

- Convenient online submission

- Rigorous peer review

- Open access: articles freely available online

- High visibility within the field

- Retaining the copyright to your article

Submit your next manuscript at $\boldsymbol{\nabla}$ springeropen.com 